\title{
Best-practice pasture renewal for forage production and sustain- ability: description of a farmer-led study and initial findings
}

\author{
N. L. BELL, W. MCG. KING, G. M. RENNIE, L. J. YATES, D. J. WILSON, S. A. HOWLETT and M. R. TROLOVE \\ AgResearch Limited, Ruakura Research Centre, Private Bag 3123, Hamilton, New Zealand
}

nigel.bell@agresearch.co.nz

\begin{abstract}
Constraints to pasture renewal success have been identified by many farmers so this multi-disciplinary study was initiated to trial and monitor the establishment, persistence and production of key forage species. Eight farms in the Bay of Plenty are being monitored. On each farm, paddocks have been selected so that a wide range of contrasting previous management and current pasture performance is covered. Initial measures of pasture production, composition, insect populations, nematodes, earthworms and interactions amongst these variables were made in February 2009. Pasture renewal significantly increased white clover yield $(\mathrm{P}<0.01)$. Black beetle (Heteronychus arator) was the major pest insect at almost all sites and populations were significantly decreased by renewal $(\mathrm{P}<0.01)$. The root-knot (Meloidogyne) and cyst (Heterodera) clover-feeding nematodes were increased in renewed paddocks, probably in response to increased clover content. Earthworm populations were significantly reduced by renewal $(\mathrm{P}<0.05)$. The relationship between pasture performance and invertebrate populations is complex but critical to pasture establishment.
\end{abstract}

Keywords: clover, grass, dry matter, black beetle, clover root weevil, grass grub, white fringed weevil, cyst nematode, root-knot nematode, earthworm, soil moisture

\section{Introduction}

The concept of changing an existing pasture to one with more desirable plant species ("pasture renewal") to gain greater plant and therefore animal productivity is not new and detailed methods to achieve this have been available for some time (e.g. Anonymous 1993; Baker 1977; Beggs 1975). Despite this, farmers are still raising questions as to the financial benefit of the renewal process with particular concern about the longer-term persistence of the new pasture.

The term "pasture renewal" is used here to denote any change from an existing pasture to one where seeds of desirable pasture plants are added to the pasture. This includes all practices from oversowing (i.e. spreading seed on the soil surface) of existing pasture to full cultivation and succession through a cropping sequence to a new pasture. For this study, the majority of pasture renewal involved herbicide spraying of existing pasture with or without full cultivation and with or without a cropping phase.

One of the factors that is likely to limit the success of pasture renewal is that much of the readily-available information is largely out of date (e.g. Anonymous 1993). With the advent of novel grass/endophyte combinations (Bluett et al. 2003; Bluett et al. 2005; Hume et al. 2007), new pests (Barratt et al. 1996), recognition of new pest species (Mercer et al. 1997) and new weeds (Tozer et al. 2008), new strategies need to be developed and communicated to farmers and contractors.

The opportunity to suppress weed and pest populations through herbicide treatment, physical disruption or host plant removal (Barker 1990; Bell et al. 2004; Bell et al. 2006; Davison et al. 1979) is one of the driving forces behind pasture renewal. Another major driver is incorporation of new germplasm to the pasture, in particular new grass/endophyte combinations (Bluett et al. 2004). The potential production and persistence of these new technologies is considerably higher than from older cultivars (Hume et al. 2007; Thom et al. 2008).

A project is now underway to investigate factors that affect pasture establishment after renewal so that recommendations can be given to farmers which will help ensure the renewal process is successful. This paper examines the pest and beneficial soil-dwelling invertebrate populations present in recently renewed and non-renewed pastures in the Bay of Plenty, as an initial step towards forming integrated pest management recommendations for pasture renewal.

\section{Materials and Methods}

Two to four paddocks on each of eight dairy farms in the Bay of Plenty were selected which had been either renewed within the previous 12 months $(n=11)$ or not $(n=12)$. Factors other than recent renewal such as renewal method, cultivation and sown germplasm, were ignored for the purposes of this paper. The farms were, with one exception, within the low summer rainfall/ high summer temperature region of the Edgecumbe plain.

Herbage was harvested monthly for January and February 2009 from three pasture exclusion cages (quadrat size $0.25 \times 0.5 \mathrm{~m}$ ) per paddock using an electric shearing handpiece to 'grazing height' (ca 2.5 $\mathrm{cm})$. Proportional composition of plant components (grasses, clover and other plants) was determined by 
visual assessments in the field, and verified through lab dissection of a third of all samples. Cut herbage was weighed, dried $\left(>48 \mathrm{~h}\right.$ at $\left.65^{\circ} \mathrm{C}\right)$ and re-weighed. Total herbage dry matter (DM) was calculated on a per hectare basis and the proportional composition was converted to DM/ ha. The herbage data considered here are from the growth period 8/9 January to 4/5 February 2009. Temperature and rainfall estimates are for the same period from Edgecumbe (NIWA virtual climate station, see Cichota et al. 2008).

Over 4-5 February 2009, 10 spade-squares were dug from each paddock along a transect bisecting the placement of the pasture cages, following the long axis of the paddock. Soil from each spade-square was handcrumbled and all insects and earthworms encountered were placed into a labelled plastic specimen container $(75$ ml) which was then filled with $70 \%$ ethanol to preserve the specimens. They were identified and recorded to family, genus or species level as appropriate.

One soil core $(2.5 \mathrm{~cm}$ diameter $\times 10 \mathrm{~cm}$ depth $)$ was taken adjacent to each spade- square for nematode determination, with the ten cores per paddock being bulked in a single labelled plastic bag. Soil from each paddock was transported to a laboratory where it was hand-crumbled, and a $100 \mathrm{~g}$ subsample used to extract nematodes over 3 days using the modified Whitehead \& Hemming tray method described by Bell \& Watson (2001). The total number of nematodes were counted and plant feeding forms identified to genus in a Doncaster counting dish (Doncaster 1962). A further ca. $100 \mathrm{~g}$ subsample of this hand-crumbled soil was weighed into labelled paper bags, dried for $48 \mathrm{~h}$ at $80^{\circ} \mathrm{C}$ then re-weighed to determine soil moisture content.

Data were analysed by REML using Genstat on untransformed or natural $\log (n+$ constant $)$ transformed data as appropriate. The constant added was the smallest non-zero value in the data range.

\section{Results and Discussion}

Overall, pasture production was low during the sampling period, with an average of less than $40 \mathrm{~kg} \mathrm{DM} / \mathrm{ha} /$ day. Soil moisture levels were low in almost all the paddocks at sampling (Table 1) which would have had a negative impact on pasture production, especially with the warm temperatures at this time of the year (mean daily maximum air temperature $25.9^{\circ} \mathrm{C}$, total rainfall $9.5 \mathrm{~mm}$ and mean daily potential evapotranspiration $5.3 \mathrm{~mm}$ for the month preceding sampling). There was no significant effect of pasture renewal on total dry matter accumulation but clover production was significantly increased in renewed paddocks at the February sampling (Table 1).

Pasture renewal significantly decreased populations of the pest insects black beetle (Heteronychus arator), grass grub (Costelytra zealandica) and white-fringed
Table 1 Raw mean plant production over 27 days (kg DM/ ha) and soil moisture (\% by weight) (means of natural log transformed data in parentheses). Note ${ }^{\star \star \star}$ $=\mathrm{P}<0.001$.

\begin{tabular}{lccc}
\hline & Not renewed & Renewed & SED \\
\hline Total DM & 918 & 1325 & 267.3 \\
Grass DM & $551(6.3)$ & $677(6.2)$ & $(0.29)$ \\
Clover DM & $107(3.3)$ & $334(5.4)$ & $(0.36)^{\star \star \star}$ \\
Other DM & 230 & 282 & 102.8 \\
Soil moisture & $21.0(3.0)$ & $19.6(2.8)$ & $(0.12)$ \\
\hline
\end{tabular}

weevil (Naupactus leucoloma), but also significantly reduced beneficial earthworm populations (Table 2). The reduction in black beetle numbers is likely to be of benefit to the new pastures because of the high numbers that would otherwise be present. Black beetle can cause damage to pastures at populations of $40 / \mathrm{m}^{2}$ or greater (Watson et al. 1980) and for the pastures that had not been renewed this threshold was reached by 10 of the 12 paddocks sampled (with a maximum of 95/ $\mathrm{m}^{2}$ being observed in one paddock). For the renewed pastures the threshold was reached in only 2 of the 11 paddocks sampled (maximum $98 / \mathrm{m}^{2}$ ). At the sampling time used here the black beetle population consisted of $26 \%$ adults, $39 \%$ pupae and $35 \%$ larvae.

At least seven of the 11 paddocks which were renewed employed soil cultivation at some point in the renewal process, including rotation through a summer crop in some cases, and this has likely had a large negative impact on invertebrate populations (Table 2). Grass-tograss renewal without cultivation can be successful in black beetle areas but requires: good control of weed grasses that may host black beetle; sowing of grass/ endophyte combinations that are resistant to adult black beetle feeding; and sowing of insecticide-treated seed to reduce resident black beetle populations and protect emerging seedlings. Although some grass/endophyte combinations provide resistance to black beetle adult feeding (Ball et al. 1994) it is thought that larval feeding is not directly affected by endophyte presence (Popay \& Ball 1998) so it is important to reduce adult populations thereby reducing egg laying in spring and subsequent summer larval populations.

Grass grub populations were significantly lower in renewed pastures (Table 2). However, the densities were generally low $\left(0-33 / \mathrm{m}^{2}\right)$ : damaging populations are considered to be above ca. $75 / \mathrm{m}^{2}$ for ryegrass/white clover swards (East et al. 1982). It is well known that grass grub can build up to damaging population levels ca. 2-3 years after pasture renewal (East et al. 1980; Watson et al. 2000). This is especially true if cultivation 
Table 2 Raw mean soil insect and earthworm abundance (number $/ \mathrm{m}^{2}$ ) (means of natural log transformed data in parentheses). Note: ${ }^{*}=\mathrm{P}<0.05 ;{ }^{*}=$ $\mathrm{P}<0.01$.

\begin{tabular}{lccc}
\hline & Not renewed & Renewed & SED \\
\hline Black beetle & $50.8(3.7)$ & $26.4(2.8)$ & $(0.30)^{\star \star}$ \\
Clover root weevil & $14.4(2.4)$ & $20.5(2.3)$ & $(0.34)$ \\
Grass grub & $9.0(2.2)$ & $0.7(1.1)$ & $(0.28)^{\star \star}$ \\
White fringed weevil & $17.1(2.7)$ & $5.9(1.7)$ & $(0.40)^{\star}$ \\
Earthworms & $139.4(4.5)$ & $60.2(3.5)$ & $(0.37)^{\star}$ \\
Total specimens & $265.8(5.5)$ & $141.6(4.7)$ & $(0.29)^{\star}$ \\
\hline
\end{tabular}

is used which disrupts the important grass grub/Serratia entomophila pathogen relationship (Robertson et al. 1999).

Both the clover root weevil (Sitona lepidus) (range $\left.0-130 / \mathrm{m}^{2}\right)$ and white fringed weevil $\left(0-43 / \mathrm{m}^{2}\right)$ populations were generally low, although the former is likely to be underestimated due to the sampling method used here being sub-optimal for adult weevil capture.

Earthworm numbers were significantly lower in renewed pastures. Earthworms contribute to soil structure (Francis \& Fraser 1998) and plant decomposition (Springett et al. 1992). However, they are susceptible to soil cultivation (e.g. Aslam et al. 1999), especially in soils with low bulk density (Yeates et al. 1998), as is likely the case for many of the soils in the present study. Identifying those paddocks which were not cultivated, and distinguishing between the different types of cultivation used in the renewal process, will allow for a more subtle examination of the effects in Bay of Plenty soil of different renewal practices on earthworm populations.

Significantly fewer total soil macro-fauna specimens were found in renewed paddocks (Table 2). In addition, there were fewer "taxa" per paddock in renewed (mean 7.3, range 4-10) than non-renewed paddocks (8.8, $7-11)$ suggesting that the diversity of these organisms may also be reduced by the renewal process.

In addition to the insects listed in Table 2, small populations of soldier fly (Inopus rubriceps) (mean 11/ $\mathrm{m}^{2}$ over all paddocks), wireworms (Elateridae) $\left(6 / \mathrm{m}^{2}\right)$, ladybirds (Coccinelidae) $\left(2 / \mathrm{m}^{2}\right)$, five unidentified beetle (Coleoptera) species (total $2 / \mathrm{m}^{2}$ ), four unidentified moth/butterfly (Lepidoptera) species $\left(1 / \mathrm{m}^{2}\right)$ and two unidentified weevil (Curculionidae) species (total 0.2/ $\mathrm{m}^{2}$ ) were present.

There was no significant effect of pasture renewal on total nematode abundance but cyst (Heterodera sp.) and root knot (Meloidogyne sp.) nematode abundance was increased (significantly for cyst nematodes) in renewed paddocks (Table 3 ). This was probably due to
Table 3 Raw mean soil nematode abundance (thousands/ $\mathrm{m}^{2}$ ) (means of natural log transformed data in parentheses). Note: ${ }^{*}=\mathrm{P}<0.05$.

\begin{tabular}{lccc}
\hline & Not renewed & Renewed & SED \\
\hline Total nematodes & 7480 & 9510 & 2250 \\
Root-knot (Meloidogyne) & $423(-2.1)$ & $930(-1.9)$ & $(0.83)$ \\
Cyst (Heterodera) & $81(0.08)$ & $235(0.24)$ & $(0.059)^{\star}$ \\
Lesion (Pratylenchus) & $720(-1.4)$ & $1062(-0.8)$ & $(0.53)$ \\
Pin (Paratylenchus) & $1506(-0.3)$ & $1050(-0.5)$ & $(0.52)$ \\
Spiral (Helicotylenchus) & $127(-2.4)$ & $109(-2.7)$ & $(0.56)$ \\
\hline
\end{tabular}

the increased abundance of their host clover plants also observed in renewed paddocks (Table 1). The individual genera of plant feeding nematodes listed in Table 3 are in order of their potential to damage pasture plants so that the high population levels of root knot (range $\left.0-5459 \times 10^{3} / \mathrm{m}^{2}\right)$ and cyst nematodes $\left(0-509 \times 10^{3} / \mathrm{m}^{2}\right)$ observed in some paddocks is likely to be of concern. As is the case for grass grub, these nematodes can increase rapidly in the first 2 to 3 years after establishment of new pasture (Sarathchandra et al. 2000), even after cropping has been used to remove plant hosts as Watson et al. (2000) found at a Bay of Plenty site.

Some of the variables measured were significantly $(\mathrm{P}<0.05, \mathrm{n}=24)$ correlated with each other. Those which were biologically sensible were: total DM, grass DM, total earthworms, total soil macro-fauna and total nematodes all positively correlated to percent soil moisture $\left(r^{2}=0.326,0.478,0.521,0.410\right.$ and 0.310 , respectively); total black beetle to percent other grass $\left(\mathrm{r}^{2}\right.$ $=0.188)$ (weed grasses being important hosts for black beetle (King et al. 1981)); and lesion (Pratylenchus sp.) nematodes positively correlated to grass DM $\left(\mathrm{r}^{2}=\right.$ 0.202) (grasses are hosts for lesion nematodes in New Zealand (Watson et al. 1995)).

From this initial sampling it appears that the main benefits of the pasture renewal conducted were increased clover production and decreased insect pest populations, particularly black beetle. The major downside was reduced earthworm populations with potential future risks from increased clover nematode and grass grub populations. Future work will replicate this study over time and will more fully investigate renewal $\times$ cultivation $\times$ cultivar $\times$ pest effects on pasture production, composition and invertebrate populations. We will also look at these effects on pasture persistence and farm system profitability.

\section{ACKNOWLEDGEMENTS}

The authors thank the members of the Bay of Plenty Focus on Dairying Group for providing both the 
impetus and the paddocks for the project. We also thank Neil Cox (AgResearch) for data analysis. This project was funded by the Ministry of Agriculture and Forestry Sustainable Farming Fund (\#08/019), with support from DairyNZ and Ballance Agri-Nutrients.

\section{REFERENCES}

Anonymous 1993. Pasture renovation manual. New Zealand Pastoral Agriculture Research Institute Ltd, $151 \mathrm{pp}$.

Aslam, T.; Choudhary, M.A.; Saggar, S. 1999. Tillage impacts on soil microbial biomass $\mathrm{C}, \mathrm{N}$ and $\mathrm{P}$, earthworms and agronomy after two years of cropping following permanent pasture in New Zealand. Soil \& Tillage Research 51: 103-111.

Baker, C.J. 1977. Some effects of cover, seed size, and soil moisture status on establishment of seedlings by direct drilling. New Zealand Journal of Experimental Agriculture 5: 47-53.

Ball, O.J.-P.; Christensen, M.J.; Prestidge, R.A.; Popay, A.J. 1994. Effect of selected isolates of Acremonium endophyte on adult black beetle (Heteronychus arator) feeding. Proceedings of the 47th New Zealand Plant Protection Conference 227-231.

Barker, G.M. 1990. Pasture renovation: interactions of vegetation control with slug and insect infestations. Journal of Agricultural Science (Cambridge) 115: 195-202.

Barratt, B.I.P.; Barker, G.M.; Addison, P.J. 1996. Sitona lepidus Gyllenhal (Coleoptera: Curculionidae), a potential clover pest new to New Zealand. New Zealand Entomologist 19: 23-30.

Beggs, J.P. 1975. Use of chemicals in pasture establishment. New Zealand Journal of Agriculture 131: 22-24.

Bell, N.L.; Watson, R.N. 2001. Optimising the Whitehead and Hemming tray method to extract plant parasitic and other nematodes from two soils under pasture. Nematology 3: 179-185.

Bell, N.L.; Addison, P.J.; Kettlewell, F.J.; Eden, T. 2004. The effect of autumn plant host removal on abundance of the clover root weevil (Sitona lepidus) and white clover seedling establishment. pp. 172-176. In: Proceedings of the 8th Australasian Conference on Grassland Invertebrate Ecology.

Bell, N.L.; Hardwick, S.; Eerens, J.P.J.; James, T.K. 2006. Managing biological succession in intensive pastoral ecosystems for improved production and sustainability. New Zealand Plant Protection 59: 271-280.

Bluett, S.J.; Thom, E.R.; Clark, D.A.; Macdonald, K.A.; Minneé, E.M.K. 2003. Milksolids production from cows grazing perennial ryegrass containing AR1 or wild endophyte. Proceedings of the New Zealand
Grassland Association: 83-90.

Bluett, S.J.; Thom, E.R.; Dow, B.W.; Burggraaf, V.T.; Hume, D.E.; Davies, E.; Tapper, B.A. 2004. Effects of natural reseeding and establishment method on contamination of a novel endophyte-infected perennial ryegrass dairy pasture with other ryegrass/ endophyte associations. New Zealand Journal of Agricultural Research 47: 333-344.

Bluett, S.J.; Thom, E.R.; Clark, D.A.; Macdonald, K.A.; Minneé, E.M.K. 2005. Effects of perennial ryegrass infected with either AR1 or wild endophyte on dairy production in the Waikato. New Zealand Journal of Agricultural Research 48: 197-212.

Cichota, R.; Snow, V.O.; Tait, A.B. 2008. A functional evaluation of virtual climate station rainfall data. New Zealand Journal of Agricultural Research 51: 317-329.

Davison, R.H.; Wrenn, N.R.; Robertson, L.N. 1979. Renovation techniques for Australian soldier fly infested pasture: a comparison of treatments. pp. 3639. In: Proceedings of the 32 nd New Zealand Weed and Pest Control Conference.

Doncaster, C.C. 1962. A counting dish for nematodes. Nematologica 7: 334-336.

East, R.; Kain, W.M.; Douglas, J.A. 1980. The effect of grass grub on the herbage production of different pasture species in the pumice country. Proceedings of the New Zealand Grassland Association 41: 105-115.

East, R.; Koller, M.S.; Willoughby, B.E. 1982. Effects of grass grub density on production of tall fescue, cocksfoot and ryegrass sown with white clover. pp. 82-85. In: Proceedings of the 35th New Zealand Weed and Pest Control Conference.

Francis, G.S.; Fraser, P.M. 1998. The effects of three earthworm species on soil macroporosity and hydraulic conductivity. Applied Soil Ecology 10: 11-19.

Hume, D.E.; Ryan, D.L.; Cooper, B.M.; Popay, A.J. 2007. Agronomic performance of AR37-infected ryegrass in northern New Zealand. Proceedings of the New Zealand Grassland Association 69: 201-205.

King, P.D.; Mercer, C.F.; Meekings, J.S. 1981. Ecology of black beetle, Heteronychus arator (Coleoptera: Scarabaeidae) - influence of pasture species on oviposition site preference. New Zealand Journal of Zoology 8: 119-122.

Mercer, C.F.; Starr, J.L.; Miller, K.J. 1997. Hostparasite relationships of Meloidogyne trifoliophila isolates from New Zealand. Journal of Nematology 29: 55-64.

Popay, A.J.; Ball, O.J.-P. 1998. The development of fungal endopytes as a pest management tool for New Zealand grasslands. pp. 374-371. In: Proceedings of the 6th Australasian Applied Entomological research Conference (Vol. 1). 
Robertson, L.; Willoughby, B.; Ward, A.; Allsopp, P. 1999. Comparative review of population dynamics of scarab pests. Proceedings of the 7 th Australasian Conference on Grassland Invertebrate Ecology: 10-20.

Sarathchandra, S.U.; Watson, R.N.; Skipp, R.A.; Burch, G.; Brown, J.A.; Cox, N.R. 2000. Microbial pathogens and plant parasitic nematodes in pastures with declining vigour. New Zealand Journal of Agricultural Research 43: 549-558.

Springett, J.A.; Gray, R.A.J.; Reid, J.B. 1992. Effect of introducing earthworms into horticultural land previously denuded of earthworms. Soil Biology \& Biochemistry 24: 1615-1622.

Thom, E.R.; Waugh, C.D.; Minneé, E.M.K.; Waghorn, G.C.; Popay, A.J. 2008. Effects of novel ryegrass endophytes on pasture production and milk production from dairy cows in northern New Zealand. p. 79. In: Multifunctional Grasslands in a Changing World, Vol II.

Tozer, K.N.; James, T.K.; Cameron, C.A. 2008. Botanical and management factors associated with Setaria pumila abundance: implications for pasture management. New Zealand Plant Protection 61: 121-126.
Watson, R.N.; Marsden, R.S.; Townsend, R.J. 1980. Farm surveying of black beetle populations in spring as an indicator of larval populations in summer. Proceedings of the 33rd New Zealand weed and pest control conference: 144-147.

Watson, R.N.; Hume, D.E.; Bell, N.L.; Neville, F.J. 1995. Plant-parasitic nematodes associated with perennial ryegrass and tall fescue with and without Acremonium endophyte. Proceedings of the 48th New Zealand Plant Protection Conference: 199-203. Watson, R.N.; Bell, N.L.; Neville, F.J.; Davis, L.T. 2000. Pest populations during the first six years in ryegrass pastures containing white or Caucasian clover. New Zealand Plant Protection 53: 410-414.

Yeates, G.W.; Shepherd, T.G.; Francis, G.S. 1998. Contrasting response to cropping of populations of earthworms and predacious nematodes in four soils. Soil and Tillage Research 48: 255-264. 